\title{
Study on effect of strength and durability parameters and performance of Self Compacting Concrete replacement with GGBS at different dosages
}

\author{
$A$ Vittalaiah ${ }^{1}$, Rathod Ravinder $^{2}$, C Vivek Kumar $^{3}$ \\ ${ }^{1}$ Assistant Professor, Department of Civil Engineering, GRIET, Hyderabad, Telangana, India. \\ ${ }^{2}$ Assistant Professor, Department of Civil Engineering, GRIET, Hyderabad, Telangana, India. \\ ${ }^{3}$ Assistant Professor, Department of Civil Engineering, GRIET, Hyderabad, Telangana, India.
}

\begin{abstract}
To investigate experimentally, the behavior of exterior beam-column joint and strength characteristics of Self Compacting Concrete (SCC) containing Viscosity Modifying Admixture (VMA), and Ground Granulated Blast Furnace Slag (GGBFS). Since there is no standard method of mix design is available for SCC. Hence mix design was arrived as per the rules of European Federation of National Associations Representing for Concrete (EFNARC). Marsh cone test was used to find the saturation of various kind of cements by adding the dosage of super plasticizer accordingly. In this investigation SCC was made by usual ingredients such as cement, fine aggregate, coarse aggregate, water and ground granulated blast furnace slag at various replacement levels $(10 \%, 20 \%, 30 \%, 40 \%$, and $50 \%)$, with that the Super Plasticizer (Glenium B233) and viscosity modifying agent (Glenium Stream 2) was used in appropriate amount for achieving the better flow in the concrete. The experiments were carried out by maintaining a constant waterpowder ratio of 0.45 . At various replacement levels the performance of freshly prepared SCC is checked by conducting tests such as slump flow, T50 slump flow, U-tube, L-box and V-funnel tests. Mechanical characteristics like Compressive, Split-tensile and Flexural strength examined. Also, the durability study for SCC after 28, 56 and 90 days curing was done by conducting a number of the tests like saturated water absorption, porosity, carbonation depth and alkalinity measurement
\end{abstract}

\section{Introduction}

Concrete is that the high wide utilized material in innovation development so significant thought is attempted for upgrading the properties of cement regarding quality, strength boundaries. Various sorts of cement are set up to build up the differed properties of cement. Up until now, this improvement are frequently managed out into four stages. The quickest is the antiquated customary quality solid that is contained just four principal materials that are concrete, water, fine and coarse totals. With a quick increment and a much bigger interest for lodging and foundation, supplemented by ongoing improvements in innovation, as multi celebrated structures and long range spans, bigger compressive quality cement was basic. When these mineral admixtures top off a piece of the pc, the estimation of SCC will be decreased prominently if the mineral admixtures are squander or mechanical result. Also, the utilization of mineral admixtures inside the production of SCC not exclusively conveys monetary points of interest anyway conjointly reduces warmth of hydration. The mix of mineral admixtures conjointly lessens the requirement for thickness increasing substance admixtures. The lower water substance of the solid expert to raised toughness, moreover to raised mechanical trustworthiness of the structure. Selfcompacting concrete (SCC) is a creative concrete that doesn't include any vibration for putting and compaction. It will flow underneath its own weight, entire filling formwork and achieving full compaction, even within the presence of clogged reinforcement. Self-compacting concrete suggests an expedient rate of concrete arrangement, with quicker construction times and simple flow across clogged reinforcement.

\section{Material properties and Investigations}

To acquire explicit experimental data that improves to grasp the mechanical behaviour and optimum dose of 
ground granulated blast furnace slag (GGBFS) OF 10\%, $20 \%, 30 \%, 40 \%$, and $50 \%$, and as partial replacement of aggregate sand as fine combination, the experimental programme was obsessed.

Cement 53-grade OPC was utilized within the examination requiring a selected gravity of three .12, fineness of cement as 7.5 nothing and primary and final setting times of cement were twenty eight minimum and 570 minimum severally.

River sand as fine aggregate was used. The specific gravity and bulk density of sand were a pair of.68 and 1.8 $\mathrm{g} / \mathrm{cm} 3$ severally. Coarse aggregate utilized is squashed rock precise aggregate passing through $20 \mathrm{~mm}$ and held on $4.75 \mathrm{~mm}$ sieve. The coarse aggregate utilized is complies to IS 383-1970 and is tested as per IS 2386-1963 for its physical properties. Its specific gravity 2.75 , Bulk density (loose state) as $1488 \mathrm{~kg} / \mathrm{m} 3$ and (compacted state) as 1559 $\mathrm{kg} / \mathrm{m} 3$. Potable water was utilized in the investigations for each mixing and hardening of specimens. GGBFS based concrete is considerably more resistant to the ingress of chloride ions in concrete separately from reduced permeability. GGBS was procured in JSW Steel Ltd, Karnataka mainly having $\mathrm{SiO} 2$ as $35.20 \%$, Al2O3 as $19 \%$ and $\mathrm{CaO}$ as $34.90 \%$.

Table 1. Proportions of GGBFS properties

\begin{tabular}{|c|c|}
\hline Description & Percentage of content \\
\hline Loss of ignition & 1.2 \\
\hline Insoluble Residue & 0.80 \\
\hline Magnesium oxide & 11 \\
\hline Sulphate & 1 \\
\hline Chloride & 0.02 \\
\hline Manganese oxide & 0.40 \\
\hline Glass content & 90 \\
\hline Moisture & 0.5 \\
\hline
\end{tabular}

Glenium B233 is an admixture of a new generation supported made-to-order polycarboxylic ether having relative density of $1.09 \&$ solid contents not 30 minutes by weight. Optimum indefinite quantity of Glenium B233 should be finished up with preliminary mixes. As a guide, some range of $500 \mathrm{ml}$ to $1500 \mathrm{ml}$ per $100 \mathrm{~kg}$ of cementitious material is for the most part suggested.

Glenium Stream 2 might be a head prepared to-utilize, fluid, natural, viscosity-modifying admixture (VMA) exclusively made for producing concrete with expanded viscosity and controlled rheological properties. During this investigation, the proportion of body modifying agent is taken as $0.082 \%$ for $1 \mathrm{~kg} / \mathrm{m} 3$.

The mix proportioning was done by the approach of EFNARC guidelines for mix design for blending concrete M40 with replacement of GGBS in various dosages is tabulated with Table 2.
Table 2. Mix proportioning for M40 Grade

\begin{tabular}{|c|c|c|c|c|c|}
\hline $\begin{array}{c}\text { Cement } \\
\mathrm{kg} / \mathrm{m}^{3}\end{array}$ & $\begin{array}{l}\text { FA } \\
\mathrm{kg} / \mathrm{m}^{3}\end{array}$ & $\begin{array}{l}\text { C.A } \\
\mathrm{kg} / \mathrm{m}^{3}\end{array}$ & $\begin{array}{l}\text { GGBFS } \\
\mathrm{kg} / \mathrm{m}^{3}\end{array}$ & $\begin{array}{c}\text { Water } \\
\mathrm{kg} / \mathrm{m}^{3}\end{array}$ & $\begin{array}{c}\text { S.P \% } \\
(\text { bwp })\end{array}$ \\
\hline 380 & 724 & 921 & 155 & 190 & 0.82 \\
\hline 1 & 1.90 & 2.42 & 0.40 & 0.45 & - \\
\hline
\end{tabular}

Various dosages of GGBS has $10 \%, 20 \%, 30 \%, 40 \%$, and $50 \%$, of several mix proportions are determined, in which the optimum dosage of GGBFS will attained for M40 grade of concrete with super plasticizer Glenium B233 and Glenium Stream 2 as viscosity modifying agent is added to the concrete while constructing the mix of the weight of the cement content. Though the specimens samples of M40 grade concrete specimens made with optimum amount of GGBFS replacement were casted.

Here is no detail system on behalf of SCC mix design and various scholarly foundations, admixtures, ready-mixed precast plants, and creating ventures have planned their particular mix proportioning ways. Further information on combine mix and on techniques of evaluating the properties of SCC is discovered within the EFNARC guidelines for SCC.

The estimation of slump is to be 550 millimeter least and of 800 millimeter most for a new SCC. The slump values and T50 values for different mixes are appeared in Table 4. And furthermore the deviation of the slump with the mixes are shown inside the Fig 1. T50 test is that the time take for a particular mix to achieve $500 \mathrm{~mm}$ slump. This facilitates to grasp the filling ability of SCC mix difference of T50 with the combination is shown in the Fig 1.

Table 3. Dosage of Superplasticizer vs Flow time

\begin{tabular}{|c|c|}
\hline \multicolumn{2}{|c|}{ Glenium B233 } \\
\hline $\begin{array}{c}\text { Super plasticizer } \\
\text { dosage (\%) }\end{array}$ & $\begin{array}{c}\text { Flow time in } \\
\text { Second }\end{array}$ \\
\hline 0.1 & 50.65 \\
\hline 0.2 & 45.97 \\
\hline 0.4 & 31.08 \\
\hline 0.8 & 22.74 \\
\hline 0.87 & 20.33 \\
\hline 0.9 & 21.45 \\
\hline 1 & 22.17 \\
\hline
\end{tabular}

Table 4. Properties of SCC mixes with \% GGBS

\begin{tabular}{|c|c|c|c|c|c|}
\hline MIX & $\begin{array}{c}\text { Slump } \\
(\mathrm{mm})\end{array}$ & $\begin{array}{c}\mathrm{T}_{50} \\
(\text { seconds) }\end{array}$ & $\begin{array}{c}\text { V funnel } \\
\text { (seconds) }\end{array}$ & $\begin{array}{c}\text { U-Box } \\
(\mathrm{mm})\end{array}$ & $\begin{array}{c}\text { L-Box } \\
\mathrm{mm}\end{array}$ \\
\hline Control Mix & 540 & 5.0 & 12.2 & 28 & 0.83 \\
\hline GGBFS-10\% & 625 & 4.0 & 11.0 & 26 & 0.85 \\
\hline GGBFS-20\% & 640 & 3.7 & 9.25 & 23 & 0.93 \\
\hline GGBFS-30\% & 650 & 3.6 & 8.4 & 21 & 0.91 \\
\hline GGBFS-40\% & 657 & 3.55 & 8.2 & 20 & 0.94 \\
\hline GGBFS-50\% & 645 & 3.8 & 8.0 & 24 & 0.91 \\
\hline
\end{tabular}

T50 test is that the time take for a specific mix to achieve 500 millimeter slump. V-funnel test is cast-off for 
flowing ability of the SCC for several mixes showing that the time taken for a sophisticated replacement is extremely less because of its fineness that happens in the mix in Vfunnel is vi secs and the most time that may be taken to drop completely is $12 \mathrm{sec}$. Utilizing L-box test the passing ability having elevated powder content and littler coarse aggregate goes plainly through the fortifying bars. the base cost of $\mathrm{H} 2 / \mathrm{H} 1$ is of 0.8 and the majority of 1.0 . U-box test is employed to seek out the passing capacity of SCC through the fortifying bars, like L-box test as stipulated by EFNARC having variation in height $\mathrm{h} 2-\mathrm{h} 1$ to be contained by the limit of 0-30 millimeter. U-Box difference in values declined for the mix comprising lesser coarse aggregates and a lot of powder materials. The values of L-box subsequent to the particular mixes are shown in Table 4.

Table 5. Mix proportioning of SCC with GGBFS percentage and their inference

\begin{tabular}{|c|c|c|c|c|c|c|c|c|}
\hline $\begin{array}{c}\text { CEMENT } \\
\mathrm{kg} / \mathrm{m}^{3} \\
\end{array}$ & $\begin{array}{l}\text { GGBS } \\
\mathrm{kg} / \mathrm{m}^{3} \\
\end{array}$ & $\begin{array}{c}\mathrm{C.A} \\
\mathrm{kg} / \mathrm{m}^{3}\end{array}$ & $\begin{array}{c}\text { WATER } \\
\mathrm{kg} / \mathrm{m}^{3}\end{array}$ & $\begin{array}{l}\text { SP } \\
\mathrm{ml}\end{array}$ & $\begin{array}{c}\text { VMA } \\
\text { ml }\end{array}$ & $\begin{array}{l}\mathbf{W} / \mathbf{P} \\
\text { ratio }\end{array}$ & MIX RATIO & CONCLUSION \\
\hline 3.25 & 4.94 & 4.55 & 1.46 & 28.30 & 2.66 & 0.45 & $1: 1.52: 1.4$ & Segregation \\
\hline 3.42 & 4.86 & 4.10 & 1.54 & 29.75 & 2.80 & 0.45 & $1: 1.42: 1.30$ & Bleeding \\
\hline 3.62 & 5.14 & 3.98 & 1.63 & 31.49 & 2.97 & 0.45 & $1: 1.42: 1.10$ & Bleeding \\
\hline 3.50 & 5.08 & 4.42 & 1.58 & 30.45 & 2.87 & 0.45 & $1: 1.45: 1.26$ & Good Flow ability \\
\hline 3.58 & 5.23 & 3.94 & 1.61 & 31.15 & 2.95 & 0.45 & $1: 1.46: 1.10$ & Excess flow \\
\hline
\end{tabular}

Table 6. Strengthened Properties of SCC mixes with \% GGBS

\begin{tabular}{|c|c|c|c|c|c|c|c|c|c|c|}
\hline \multirow{2}{*}{$\mathbf{w} / \mathbf{p}$} & \multirow{2}{*}{ Mix no } & \multicolumn{3}{|c|}{ Compressive Strength (in days) } & \multicolumn{3}{|c|}{ Split Tensile Strength (in days) } & \multicolumn{3}{|c|}{ Flexural Strength (in days) } \\
\hline & & 7 & 28 & 56 & 7 & 28 & 56 & 7 & 28 & 56 \\
\hline \multirow{6}{*}{0.45} & Control & 24.24 & 44.55 & 47.64 & 0.64 & 1.73 & 2.11 & 1.12 & 3.14 & 3.84 \\
\hline & GGBFS- $10 \%$ & 25.12 & 46.2 & 49.84 & 0.77 & 1.84 & 2.24 & 1.24 & 3.3 & 3.94 \\
\hline & GGBFS-20 & 26.99 & 47.4 & 51.03 & 0.84 & 1.95 & 2.48 & 1.35 & 3.45 & 4.19 \\
\hline & GGBFS-30 & 26.01 & 45.2 & 53.14 & 0.76 & 1.72 & 2.69 & 1.28 & 3.35 & 4.55 \\
\hline & GGBFS-40 & 23.77 & 42.3 & 50.14 & 0.71 & 1.48 & 2.54 & 1.1 & 3.19 & 4.36 \\
\hline & GGBFS-50 & 22.12 & 40.41 & 49.68 & 0.58 & 1.31 & 2.35 & 1.04 & 3.04 & 4.16 \\
\hline
\end{tabular}
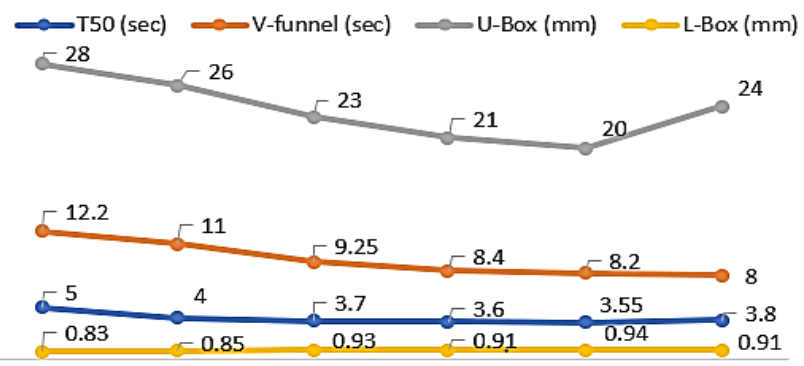

Control Mix GGBFS-10\% GGBFS-20\% GGBFS-30\% GGBFS-40\% GGBFS-50\% Fig.1. Fresh properties of SCC mix with \% GGBFS

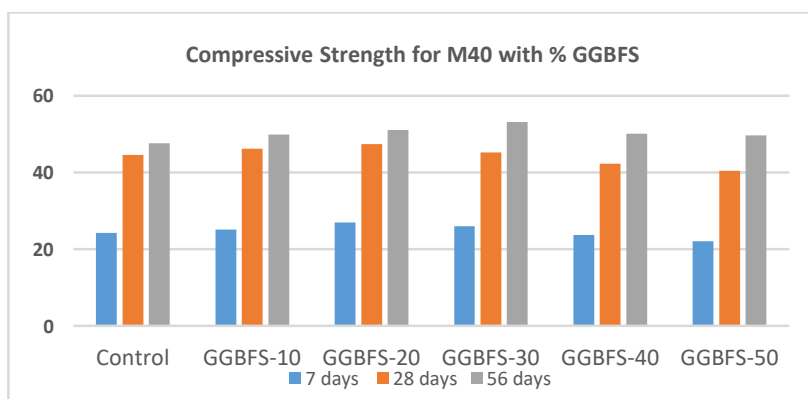

Fig.2. Compressive Strength of SCC with \% GGBFS

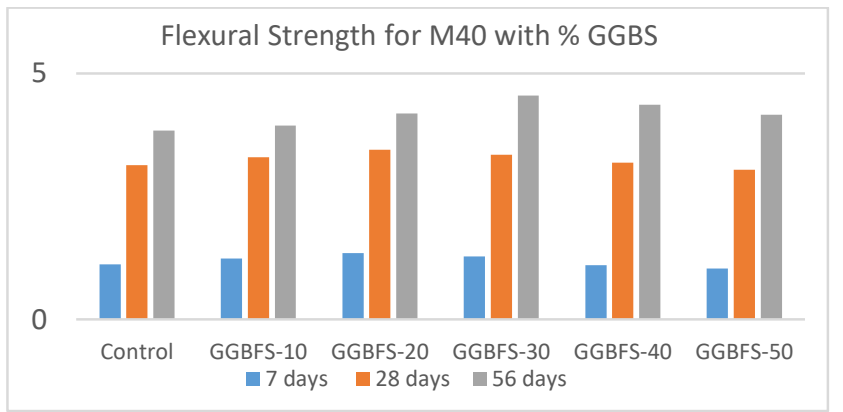

Fig.3. Flexural Strength of SCC with \% GGBFS

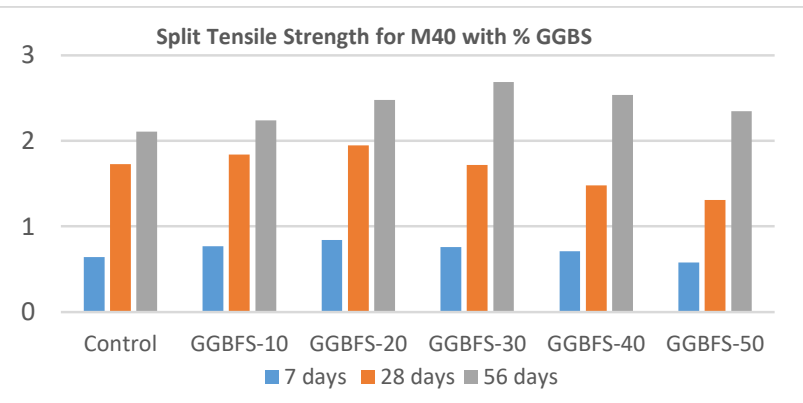

Fig.4. Split Tensile Strength of SCC with \% GGBFS 
Table 6. Water Absorption \% SCC mixes with \% GGBS

\begin{tabular}{|c|c|c|c|}
\hline \multirow{2}{*}{$\begin{array}{c}\text { Replacement of } \\
\text { cement with } \\
\text { GGBFS (\%) }\end{array}$} & \multicolumn{3}{|c|}{ Water absorption (\%) } \\
\cline { 2 - 4 } & 7 days & 28 days & 56 days \\
\hline $0 \%$ & 3.89 & 3.63 & 3.45 \\
\hline $10 \%$ & 3.64 & 3.57 & 3.25 \\
\hline $20 \%$ & 3.48 & 3.24 & 3.12 \\
\hline $30 \%$ & 3.01 & 2.92 & 2.70 \\
\hline $40 \%$ & 2.78 & 2.45 & 2.41 \\
\hline $50 \%$ & 2.11 & 1.94 & 1.86 \\
\hline
\end{tabular}

Table 7. Effective porosity for SCC mixes with \% GGBS

\begin{tabular}{|c|c|c|c|}
\hline \multirow{2}{*}{$\begin{array}{c}\text { Mix Proportions } \\
\text { with GGBFS (\%) }\end{array}$} & \multicolumn{3}{|c|}{ Effective porosity (\%) } \\
\cline { 2 - 4 } & 7days & 28days & 56days \\
\hline $0 \%$ & 6.95 & 6.70 & 6.43 \\
\hline $10 \%$ & 6.90 & 6.66 & 6.31 \\
\hline $20 \%$ & 6.68 & 6.26 & 6.00 \\
\hline $30 \%$ & 6.39 & 6.00 & 5.81 \\
\hline $40 \%$ & 6.18 & 5.20 & 5.00 \\
\hline $50 \%$ & 5.86 & 4.30 & 4.00 \\
\hline
\end{tabular}

Table 8. Alkalinity for SCC mixes with \% GGBS

\begin{tabular}{|c|c|c|c|}
\hline $\begin{array}{c}\text { Replacement of } \\
\text { cement with GGBFS } \\
(\%)\end{array}$ & \multicolumn{3}{|c|}{$\mathrm{pH}$} \\
\cline { 2 - 4 } & 7 days & 28 days & 56 days \\
\hline $0 \%$ & 11.97 & 11.8 & 11.61 \\
\hline $10 \%$ & 11.01 & 11.0 & 10.57 \\
\hline $20 \%$ & 10.85 & 10.8 & 10.13 \\
\hline $30 \%$ & 10.46 & 10.4 & 9.94 \\
\hline $40 \%$ & 10.03 & 9.93 & 9.60 \\
\hline $50 \%$ & 9.94 & 9.79 & 9.25 \\
\hline
\end{tabular}

Table 9. Sulphate Attack for SCC mixes with \% GGBS

\begin{tabular}{|c|c|c|c|}
\hline \multirow{2}{*}{$\begin{array}{c}\text { Mix Proportions with } \\
\text { GGBFS (\%) }\end{array}$} & \multicolumn{3}{|c|}{ Avg. reduction in weight (\%) } \\
\cline { 2 - 4 } & 7 days & 28 days & 56 days \\
\hline $0 \%$ & 1.48 & 2.14 & 2.80 \\
\hline $10 \%$ & 1.27 & 1.97 & 2.56 \\
\hline $20 \%$ & 1.16 & 1.90 & 2.47 \\
\hline $30 \%$ & 1.09 & 1.82 & 2.31 \\
\hline $40 \%$ & 1.05 & 1.72 & 2.29 \\
\hline $50 \%$ & 1.01 & 1.65 & 2.22 \\
\hline
\end{tabular}

Table 10. Carbonation Depth for SCC mixes with \% GGBS

\begin{tabular}{|c|c|c|c|}
\hline \begin{tabular}{c} 
Cement $\begin{array}{c}\text { Replacement with } \\
\text { GGBFS } \\
(\%)\end{array}$ \\
\cline { 2 - 4 }
\end{tabular} & \multicolumn{3}{|c|}{ Depth of penetration (mm) } \\
\hline $0 \%$ & 63 & 58 & 51 \\
\hline $10 \%$ & 52 & 47 & 40 \\
\hline $20 \%$ & 45 & 42 & 34 \\
\hline $30 \%$ & 42 & 40 & 32 \\
\hline $40 \%$ & 39 & 37 & 30 \\
\hline $50 \%$ & 36 & 35 & 29 \\
\hline
\end{tabular}

\section{Conclusions}

In light of the trial examinations and test outcomes the accompanying ends are recorded as underneath -

1. For $30 \%$ GGBFS substitution levels, the new properties explicit were magnificent as related with $10 \%$ percent, $20 \%, 40 \%$ and $50 \%$ GGBFS replacement therefore if increasing the GGBFS replacement it can be a stronger effective concrete in self-compacting concrete.

2. The Glenium Stream two having 0.082 with no need a $\%$ of 30 minutes GGBFS having higher fluidity and viscosity of the glue is managed and composed by cautious choice and proportioning of the concrete and augmentations, by restricting the water/powder proportion and afterward by expansion of super plasticiser and (as a discretionary) a thickness changing admixture overseeing these instruments of SCC, their similarity and cooperation is significant to accomplishing great filling capacity, passing capacity and protection from segregation..

3. In the vicinity accessible VMA contains a fundamental effect on the ongoing properties of self-compacting concrete. Addition of GGBFS brings about achieving extra viscous mix. For $30 \%$ GGBFS substitution, the compressive strength watched higher when compared with $10 \%, 20 \%, 40 \%$ and $50 \%$ GGBFS replacement having higher strengths for 7, 28 and 56 days compared with the conventional cement.

4. Increasing the substitution rates of mineral admixtures have diminished compressive strength and increment both split strength and Flexural strength. In the durability properties, the water absorption percentage is increased in SCC with GGBFS from $0 \%$ and further decreased in $50 \%$. The optimum values for porosity varies from $20 \%$ to $30 \%$ to the SCC mixes with GGBFS. The alkalinity values in terms of $\mathrm{pH}$ increased in $0 \%$ and lowered down in $50 \%$.

5. The average reduction in weight for sulphate attack test is having 2.18 and 2.80 for 28,56 days to $0 \%$ and having a optimum values for $30 \%$ and decreased for $50 \%$. The depth of penetration in carbonation test is very low in $50 \%$ for $7,28,56$ days.

\section{References}

1. Bassuoni, M.T. Nehdi, M.L.(2009) "Durability of self-consolidating concrete to different exposure regimes of sodium sulfate attack" Materials and Structures Vol. 42 pp. 1039-57.

2. Bonen, D. Shah, S.P.(2005) "Fresh and hardened properties of self-consolidating concrete construction". Progress in Structural Engineering Materials, Vol. 7 pp. 14-26.

3. Tummala Suresh Kumar, Kosaraju Satyanarayana, Materials Today: Proceeding, 26 (2), 3228-3233, (2020)

4. Gesoglu, M. Güneyisi, E. Özbay, E. (2009) "Properties of self-compacting concretes made with 
binary, ternary, and quaternary cementitious blends of fly ash, blast furnace slag, and silica fume" Construction and Building Materials Vol. 23 pp.1847-1854.

5. MuctebaUysal, Mansur Sumer, (2011). "Performance of self-compacting concrete containing different mineral admixtures" Construction and Building materials Vol. 25 No. 11 pp. 4112-4120.

6. BIS 1959 IS 516-1959 (reaffirmed 1997), "Methods of Tests for Strength of Concrete, Bureau of Indian Standards", New Delhi.

7. BIS 1970 IS 383-1970 (reaffirmed 1997), "Specification for Coarse and Fine Aggregates from Natural Source for Concrete", New Delhi.

8. BIS 1987 IS 12269-1987 (reaffirmed 1999), "Specification for 53 grade Ordinary Portland Cement", New Delhi.

9. BIS 2000 IS 456-2000 (reaffirmed 2005), "Plain and Reinforced Concrete - Code of Practice", Fourth Revision, pp.14, 2000. 